\title{
Production of Okara Food Material Containing High Dietary Fiber
}

\author{
Yokosawa Hirotsugu* and TAKEnAKa Tetsuo* \\ * Faculty of Agriculture, Tamagawa University \\ 6-1-1 Tamagawa-Gakuen, Machidashi, Tokyo 194-8614
}

\begin{abstract}
The removal of water-insoluble protein existing in Okara by chemical and enzymatic treatment had done in order to obtain dietary fiber (DF) of high purity, and DF were observed through scanning electron microscope (SEM). The combining chemical and enzymatic treatments were highly effective in extracting DF of high purity from Okara. The following treatments were performed: Okara was treated chemically at pH10.0, and then by enzymes, protease (method-1), and Okara was treated chemically at pH10.0, followed by enzymes, pectinase first and protease (method-2). Both Okaras were DF of high purity. Okara obtained by method- 1 contained $96.3 \% \mathrm{TDF}, 3.9 \%$ protein, and that by method -2 contained $98.6 \%$ TDF, $1.4 \%$ protein. It was observed by SEM that particles of Okara obtained by method- 2 was much the same in form as cellulose powder on the market. On the other hand, Okara by method -1 had a large surface area and was porous. Consequently, chemical and enzymatic treatment Okara (CETO) obtained in this study was considered to be used in a similar way to cellulose on the market, and also to be used for adsorbent substances by taking advantage of its porosity.
\end{abstract}

(Received May 5, 2000; Accepted Jun. 14, 2000)

Recently, it has been proved that DF contribute greatly to maintaining human health, and the public is growing more and more interested in fibers $^{1)}$. Okara is rich in protein, which is left after producing soymilk, lipids. As for TDFs, pectin for water-soluble, and cellulose, hemicellulose and lignin for water-insoluble, account for more than $50 \%$ of $\mathrm{Okara}^{2}$. Soybean seed contains about $40 \%$ of protein, and protein, which is extracted from soybeans using water or saline, is about $90 \%$. However, approximately 35 to $40 \%$ of protein is left in Okara, around $50 \%$ of which remains even when washing the Okara in water ${ }^{3) ~ 6)}$. This is considered to be due to the following reasons: water soluble globulin exists in soybeans, becomes insoluble in water by heating to produce soymilk or physically entangles with other component in okara. In this report, the main purpose was to remove water-insoluble protein existing in Okara in order to obtain DF of high purity, and DF, purified through chemical treatment or enzymatic treatment, were observed through SEM.

\section{Materials and Methods}

\section{Materials and chemicals}

Okara was prepared in our laboratory according to following method (Soaking: Dry whole soybeans were cleaned, measured and then soaked in water overnight. Draining: The soaked beans were drained and rinsed with fresh water three times. Grinding: The wet, clean soybeans were now ground in a mill with the addition of fresh water. Boiling: The bean slurry was boiled for 10 min. Filtering: The bean slurry is filtered through a cloth sack with a wooden level press), was lyophilized and stored at $5^{\circ} \mathrm{C}$ until use. The following enzymes were purchased: Protease-A, Protease-M, Protease-P, Protease-S, Prolezer, Hemicellulase-90 from Amano Seiyaku Co. 
(Nagoya, Japan), Pectinase-SS, Cellulase-3S from Yakult Yakuhin Kougyo Co. (Tokyo, Japan).

\section{Chemical analysis}

The protein content was analyzed by the micro -kjeldahl method $(\%$ protein $=\% \mathrm{~N} \times 5.71)$ and free amino acids contents were by Auto amino acid analyzer. The lipid content was analyzed by the method of Soxhlet extraction, free fatty acids were by the method of alkaline titration. Free sugar content was analyzed by HPLC according to TAIRA et $a l^{7}$., and dietary fiber was analyzed by the method of detergent fiber according to Van SOEST $^{8}$. The ash content was analyzed in the usual way ${ }^{9}$.

\section{Chemical treatment}

Dried Okara $(10 \mathrm{~g})$ was added to 20 times $\mathrm{v} / \mathrm{w}$ of distilled water. The $\mathrm{pH}$ value of each suspension was adjusted in range of 2 to 12 with $1 \mathrm{~N} \mathrm{HCl}$ and $\mathrm{NaOH}$, and they were all treated for $60 \mathrm{~min}$ at $98^{\circ} \mathrm{C}$ and centrifuged $(15,000 \times \mathrm{g})$ for $15 \mathrm{~min}$ to extracted the protein from Okara.

\section{Enzymatic treatment}

Dried Okara (10g) was added to 20 times v/w of distilled water. Optimal conditions of various enzymes were adapted as the manufacture recommended. After enzyme reaction, they were heated in boiling water for $3 \mathrm{~min}$ to inactivate enzymes and centrifuged $(15,000 \times \mathrm{g})$ for $10 \mathrm{~min}$ to extract protein from Okara.

\section{Combining Chemical and Enzymatic treat-} ment

Okara was performed by chemical treatment at $\mathrm{pH} 10$, and then by enzymatic treatment as noted above.

\section{Scanning electron microscope (SEM)}

Sample were prepared by the freeze-drying, coated with gold and observed with JEOL-7800 at $20 \mathrm{KV}$.

\section{Staining of soybean tissue}

A piece of soybean was stained by ruthenium red for pectin and lignin and by toluidine blue for cellulose, hemicellulose to see how TDF were distributed in each part of soybean ${ }^{10,11}$.

\section{Results and Discussion}

1. Chemical composition between Okara from the Tofu factory and Okara prepared in our laboratory

Five kinds of Okara were compared in composition, and on an average, dry Okara contained $28.2 \%$ protein, $51.9 \%$ TDF. all samples contained high fiber contents, and it was suggested that Okara can be used for making fiber materials. Then, Okara prepared in our laboratory was used in this report.

\section{SEM of Okara and each part of soybean}

It was considered that Okara particles take different forms as they are ground to extract protein. In fact, different forms of Okara particles were observed through SEM, most of which were honeycombed (Fig. 1). In order to identify which part was filled with holes, soybeans were separated into three parts such as cotyledons, seed coats and hypocotyls, which were each examined by SEM. As a result, it was noted that these honeycomb particles exist mainly in cotyledons (Fig. 2). Honeycomb particles were also noted in hypocotyls, and each hole was smaller and finer than in cotyledons. Both protein and TDF contents were measured for cotyledons, seed coats, and hypocotyls, respectively, indicating that soybean cotyledons, which account for most of Okara, contain more of protein than TDF (Table 1). And a piece of soybean was stained by ruthenium red for pectin and lignin, toluidine blue

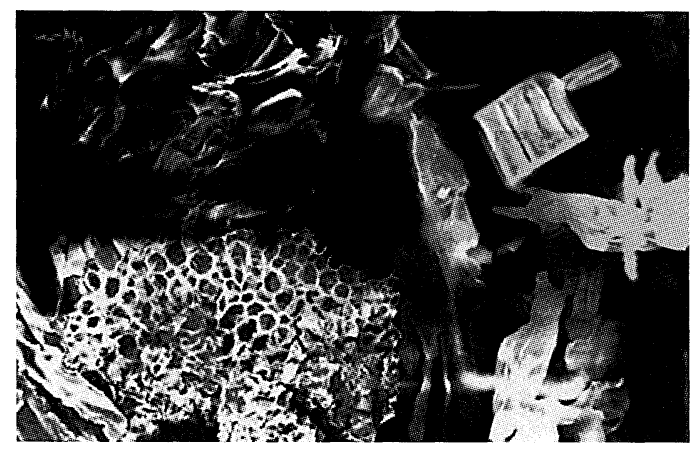

Fig. 1 Scanning electron microscopic photograph of Okara particles $(\times 100)$ 


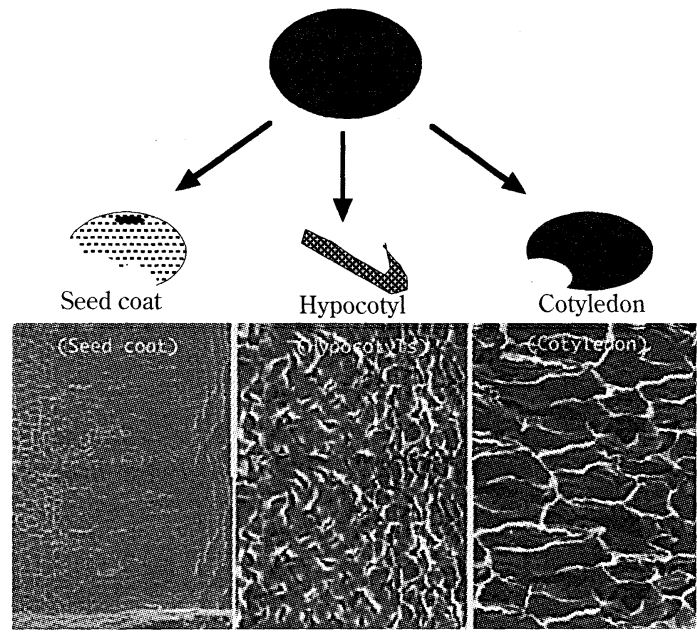

Fig. 2 Scanning electron micrographs of three parts from Soybean $(\times 500)$

Table 1 Protein and TDF contents of whole soybean and each part of soybean

\begin{tabular}{lcc}
\hline & TDF $(\%)$ & Protein $(\%)$ \\
\hline Whole & 32.28 & 41.21 \\
Colyledon & 33.32 & 44.46 \\
Seed coat & 88.52 & 2.83 \\
hypocotyl & 49.16 & 50.33 \\
\hline
\end{tabular}

Reported values are mean $(n=3)$

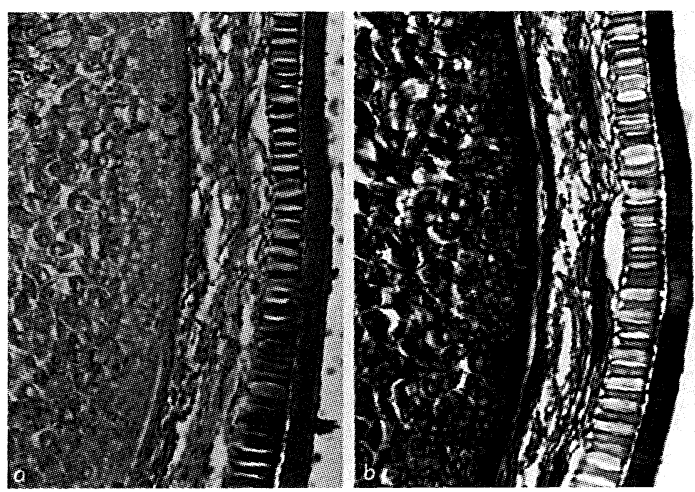

Fig. 3 Micrographs of soybean a:stained by toluidine blue. b:stained by rutenium red.

for cellulose and hemicellulose to see how TDF were distributed in cotyledons (Fig. 3). There were much of cellulose and lignin noted in seed coats and hypocotyls, and pectin as well as cellulose extensively distributed in cotyledons.

\section{Removal of protein from Okara}

Okara was suspended in water, followed by heating, and then repeated protein extraction was carried out from the suspension. This was reported by KUGIMIYA ${ }^{12)}$ to cause much of protein to be eluted from Okara. It was noted through SEM that Okara particles get smaller by heating, which was considered to result from their decomposition, leading protein to be released from physical restraint and be eluted. But a lot of protein remained in Okara after heating, and it was suggested that in order to extract TDF of high purity from Okara only heating is not enough and protein, which is stuck to Okara particles, needs to be removed (result not shown).

\section{Chemical treatment}

The TDF and protein contents of Okaras (chemical treatment Okara, CTO) by chemical treatment were measured respectively (Table 2). The protein content decreased as acidity or alkalinity got stronger, and it was reduced to about $10 \%$ at more than $\mathrm{pH} 10$. On the other hand, the TDF content increased in proportion to acidity or alkalinity. However, there was less

Table 2 TDF and protein contents of CTOs by chemical treatment

\begin{tabular}{rrccc}
\hline & Yield $^{1)}(\%)$ & $\mathrm{TDF}^{2)}(\%)$ & Protein $^{3)}(\%)$ \\
\hline Okara & 100 & 30.28 & 24.6 \\
Okara in pH & 1.5 & 9.2 & 96.6 & 2.3 \\
& 2.0 & 13.5 & 92.4 & 5.2 \\
3.0 & 21.1 & 81.6 & 18.1 \\
4.0 & 46.5 & 75.4 & 23.3 \\
5.0 & 70.7 & 57.1 & 42.5 \\
6.0 & 77.3 & 43.1 & 44.1 \\
7.0 & 90.6 & 40.2 & 42.7 \\
8.0 & 87.9 & 51.1 & 39.5 \\
9.0 & 80.5 & 64.7 & 27.7 \\
10.0 & 77.0 & 82.1 & 11.2 \\
11.0 & 67.9 & 86.0 & 9.3 \\
12.0 & 34.9 & 89.0 & 9.1 \\
\hline
\end{tabular}

1 ) : Okara by acid and alkaline treatment/intact okara $\times 100$.

2 ) : DF / Okara by acid and alkaline treatment $\times 100$.

3 ) : Protein / CTO, measured by micro-kjedahl metod (nitrogen coefficient : 5.71) $\times 100$.

Reported values are mean $n=3$. 

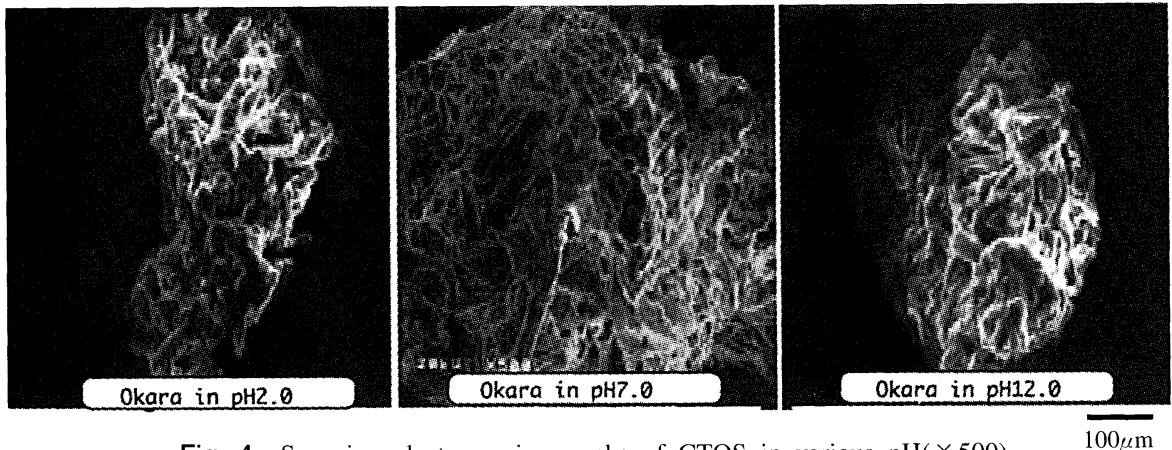

Fig. 4 Scanning electron micrographs of CTOS in various $\mathrm{pH}(\times 500)$

Okara collected from the solution as acidity got higher, which suggested that treating Okara with acid is not appropriate. And Okaras, which had been tested at $\mathrm{pH} 2,7$ or 12 , and at $98^{\circ} \mathrm{C}$, were seen under SEM, and its average grain diameter were about 300 and $500 \mu \mathrm{m}$ for $\mathrm{pH} 2$ and $\mathrm{pH} 12$ respectively while about $1500 \mu \mathrm{m}$ for pH7 (Fig. 4). Accordingly, one of the factors in the decline of protein content was considered to be Okara particles, which get smaller. However, there was some discoloration noted at pH11 and over, from which $\mathrm{pH} 9$ to 10 was judged to be appropriate for preparing CTO.

\section{Enzymatic treatment}

The TDF and protein contents of Okaras (Enzymatic Treatment Okara, ETO) by enzymatic treatment were measured. As for protease, the protein content decreased to some $12 \%$. Regarding pectinase, cellulase, and hemicellulase, however, there was a decline observed in the protein content (Table 3). It was, therefore, deemed that protein in Okara is bonded with TDF in some ways or TDF get physically entangled in protein. It was then suggested that co-use of protease and fiber lytic enzymes is greatly effective in extracting TDF of high purity from Okara. Okara was treated through combined use of these enzymes, i.e. treated with protease $\mathrm{A}$ and then with fiber lytic enzymes, and viceversa. Protein and TDF contents of ETO were measured after those treatments. As a result, the latter showed a better effect. And pectinase was more
Table 3 Protein and TDF contents of Okara treated with various enzymes

\begin{tabular}{cccc}
\hline & Yield $^{1)}(\%)$ & $\operatorname{TDF}^{2)}(\%)$ & $\operatorname{Protein}^{3)}(\%)$ \\
\hline control & 90.5 & 46.1 & 43.3 \\
with Protease & 65.1 & 74.9 & 12.1 \\
\hline control & 90.4 & 45.3 & 44.5 \\
with Pectinase & 74.7 & 56.4 & 34.8 \\
\hline control & 90.7 & 43.7 & 42.3 \\
with Cellulase & 71.2 & 38.4 & 33.7 \\
\hline control & 90.2 & 44.0 & 43.6 \\
with Hemicelluase & 81.4 & 54.4 & 38.5 \\
\hline
\end{tabular}

control: sample was treated in the same condition without enzymes.

1) : ETO / intact okara $\times 100$.

2) $: \mathrm{DF} / \mathrm{ETO} \times 100$

3 ) : Protein $/$ ETO $\times 100$.

Reported values are mean $n=3$.

effective in removing protein among fiberlytic enzymes, and the protein content decreased to about $6 \%$ (Table 4). In the plant body, pectin generally turns into pectate, which functions like a bonding agent and remains plant-shaped. As Figure 4 shows, there was pectin observed in any parts of soybeans, showing that pectinase treatment was effective. Therefore, it was considered that pectin, which is stuck between Okara particles, is hydrolyzed by pectinase and accordingly protein gets easily removed. In addition, there was a decline noted by SEM in the grain diameter not only due to chemical 
Table 4 TDF and protein contents of ETOs

\begin{tabular}{|c|c|c|c|}
\hline & Yield $^{1\rangle}(\%)$ & $\operatorname{TDF}^{2)}(\%)$ & Protein $^{3)}(\%)$ \\
\hline \multicolumn{4}{|l|}{ Protease } \\
\hline$\longrightarrow$ Pectinase & 64.6 & 86.6 & 12.0 \\
\hline \multicolumn{4}{|l|}{ Protease } \\
\hline$\longrightarrow$ Cellulase & 63.7 & 85.4 & 11.2 \\
\hline \multicolumn{4}{|l|}{ Protease } \\
\hline$\longrightarrow$ Hemicellulase & 64.3 & 87.2 & 11.9 \\
\hline \multicolumn{4}{|l|}{ Pectinase } \\
\hline Protease & 52.1 & 89.9 & 6.3 \\
\hline \multicolumn{4}{|l|}{ Cellulase } \\
\hline Protease & 56.8 & 88.7 & 9.0 \\
\hline \multicolumn{4}{|l|}{ Hemicellulase } \\
\hline Protease & 58.2 & 89.1 & 9.5 \\
\hline
\end{tabular}

1) : ETO / intact okara $\times 100$.

2) $: \mathrm{DF} / \mathrm{ETO} \times 100$.

3) : Protein $/$ ETO $\times 100$.

Reported values are mean $n=3$.
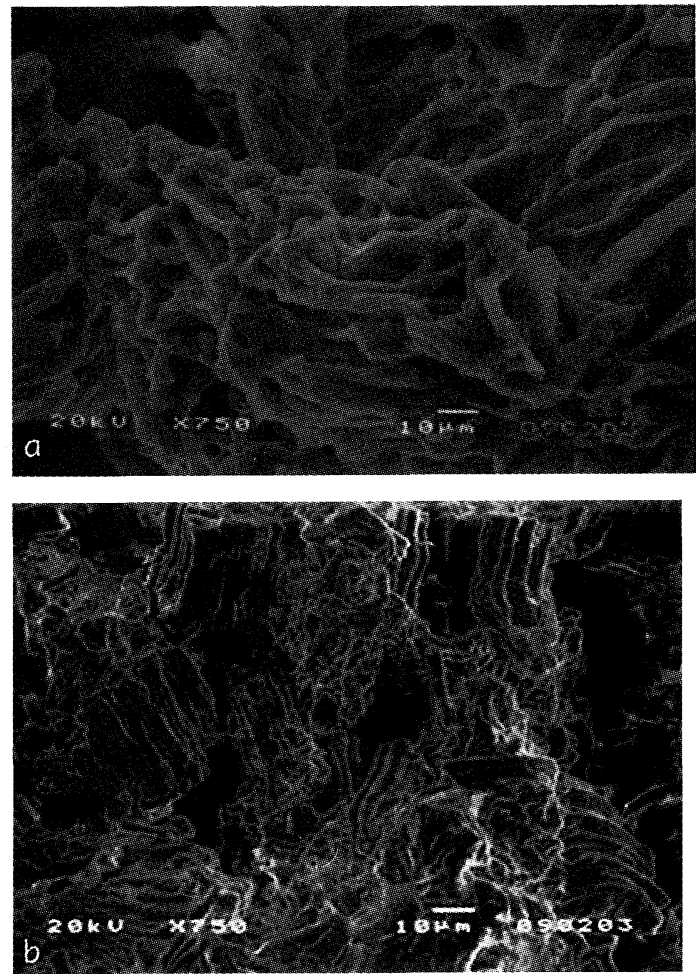

Fig. 5 Scanning electron micrographs of $\operatorname{Okara}(\times 750)$ a:treatment by protease.

b:treatment by protease and pectinase.

treatment, but also to its structural change (Fig. $5)$. It is not mentioned in this report, but in order to enhance the degradation rate of pectinase, its amount and the time of its being kept under a certain condition were both increased and there was no significant change noted in the protein and TDF contents. It was proved, therefore, that enzymes which are effective in removing protein are pectinase and protease. But protein was still observed, which suggested that treatment using enzymes only is not adequate when obtaining TDFs of high purity.

6. Combining chemical and enzymatic treatments

The results of chemical treatment and enzymatic treatment showed that combining chemical and enzymatic treatments is highly effective in extracting TDF of high purity from Okara. In order for Okara particles to be degraded by pectinase, the followings were performed: Okara was treated chemically in the same way, and then by pectinase (Method-1), and Okara was treated chemically at $\mathrm{pH} 10$, and then by enzymes, pectinase first and protease (Method -2). As a result, the TDF content was higher in Method-2 than Method-1 and protein content was lower (Table 5). Okaras (CETO, chemical and enzymatic treatment Okara) prepared by Method -1 or Method- 2 were seen under SEM, showing decrease and uniformity of the grain diameter (Fig. 6). Enzymatic treatment was able to be performed quickly and effectively as chemical treatment was applied to Okara particles in

Table 5 Protein and TDF contents of CETOs

\begin{tabular}{|c|c|c|c|}
\hline Method & Yield $^{1)}(\%)$ & $\operatorname{TDF}^{2)}(\%)$ & $\operatorname{Protein}^{3)}(\%)$ \\
\hline $\begin{array}{c}\text { Reaction } 1 \\
(\mathrm{pH} 10,60 \mathrm{~min} ., \\
\downarrow \\
\text { Protease }\end{array}$ & 49.5 & 96.3 & 3.9 \\
\hline $\begin{array}{c}\text { Reaction } 2 \\
\left(\mathrm{pH} 10,60 \mathrm{~min} ., 98^{\circ} \mathrm{C}\right) \\
\downarrow \\
\text { Pectinase } \\
\longrightarrow \text { Protease }\end{array}$ & 48.5 & 98.6 & 1.4 \\
\hline
\end{tabular}

1) : CETO / intact okara $\times 100$.

2) $: \mathrm{DF}$ of $\mathrm{CETO} \times 100$

3 ) : Protein / ETO $\times 100$.

Reported values are mean $\mathrm{n}=3$. 

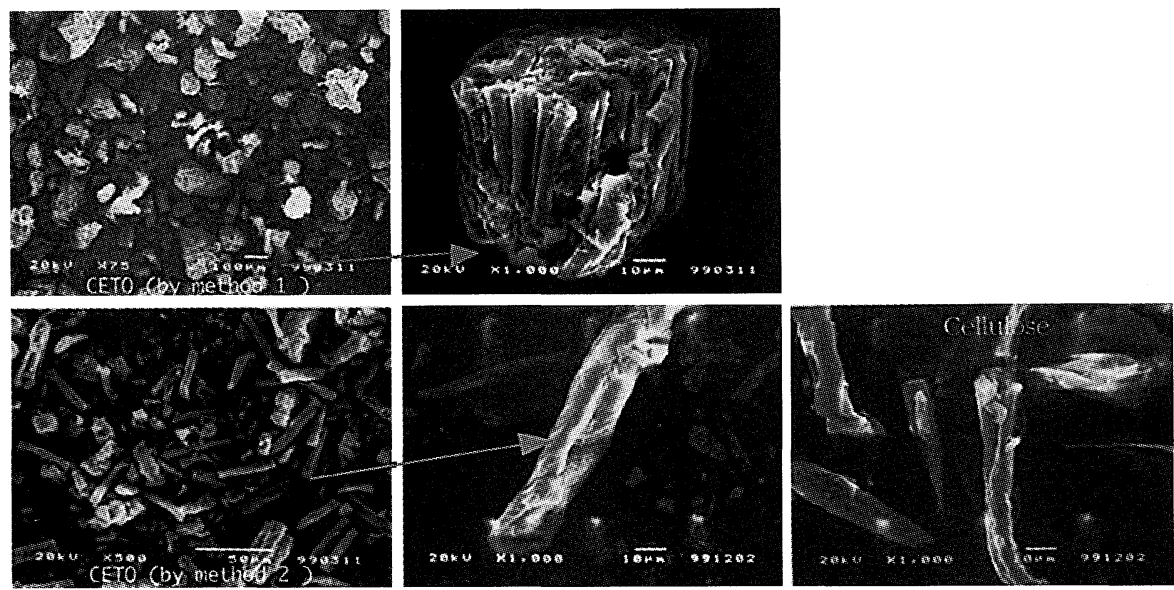

Fig. 6 Scanning electron micrographs of two types of CETO and Cellulose (on the market)

advance to degrade them. As Fig. 6 shown, It was observed by SEM that Okara (CETO) obtained in method- 2 was much the same in form as cellulose powder on the market. On the other hand, Okara removed in method-1 had a large surface area and was porous. Consequently, CETO obtained by method-2 in this study was considered able to be used in a similar way to cellulose on the market, and CETO by method- 1 was to be used for adsorbent substances by taking advantage of its porosity, which is because CETO is currently under study. In this way, it was suggested that TDF extracted from Okara is able to be used not only as fibers themselves, but also in various fields.

ACKNOWLEDGEMENTS The authors thank Dr. TABuchI, T., Tamagawa University for his valuable suggestions.

\section{REFERENCES}

1) Takahashi, T., Egashira, Y., Ayano, H., Maeda, H. and Terashima, M.: J. Jpn. Soc. Nutr. Food Sci., 45, 227 (1992)

2) Takeyama, E., Akagi, M., Daimon, K. and Окамото, M.: Shokuhinkaihatu, 19, 8 (1988) (in
Japanese)

3) Nakamura, I., Okubo, K. and Yamauchi, M.: Nippon Shokuhin Kagaku Kogaku gakkaishi, 36, 318 (1989) (in japanese)

4) Asano, M., Endo, I. and Yamauchi, F.: Nippon Shokuhin Kagaku Kogyo Gakkaishi, 40, 323 (1993) (in japanese)

$5)$ Ingh, B. B. P. and Kulshrestha, N.: J. Food Sci., 52, 1538 (1987)

6) Hsu, K. H., Kim, C. J. and Wilson, L. A.: Cereal. Chem., 60, 208 (1983)

7) Taira, H., Tanaka, H. and Saito, M. J.: Nippon Shokuhin Kagaku Kogyo Gakkaishi, 36, 968 (1989) (in japanese)

8 ) Soest, V. P. J. : J. Assoc. off. Anal. Chem., 46, 829 (1993)

9) The Association of Official Analytical chemists: official Mathods of Analysis of the Assoc. Offic. Anal. Chemists, 12th ed., 22 (1975)

10) Tabuchi, T., Wada, S. and Arai, N.: Acta Hort., 487, 71 (1999) (in japanese)

11) Arai, N., Sugiyama, F., Seo, M. and Tabuchi, T.: J.japan.Soc. Hort. Sci., 67, 286 (1998) (in japanese)

12) KugrmiYa, M.: Nippon Shokuhin Kagaku Kogaku Gakkaishi, 42, 273 (1995) (in japanese) 


\section{おからを原料とする食物繊維の調製法}

\section{横沢広嗣* ·竹中哲夫* \\ *玉川大学農学部}

（テ194-8610 東京都町田市玉川学園 6-1-1）

昨今，食品に含まれる食物繊維が人の健康維持に深く 関与していることが明らかにされ，食物繊維に対する社 会的関心が高まっている。一方，生扔からには，豆乳と してしぼりきらなかったタンパク質をはじめ，脂質，繊 維質が多量に含まれており，中でも繊維質に関しては， 水溶性食物繊維としてペクチン, 水不溶性食物繊維とし てセルロース，ヘミセルロース，リグニンが全体で約 $50 \%$ 以上含まれている。

大豆種子中には，約 $40 \%$ のンパク質が含まれ，脱
脂大豆を水または食塩水で抽出すると，約 $90 \%$ が抽出 される。しかし，おから中に約 $35 \sim 40 \%$ のンパク質 が残存し，これらを除去するために酵素処理や $\mathrm{pH}$ 処 理を施しても，効果を得にくい。この要因として，大豆 中に含まれる不溶性グロブリンの存在，おから調製時の 加温による不溶化，繊維質に物理的に抱き込まれて溶出 しずらい形態を持つタンパク質の存在が考えられる。本 報告では，高純度の食物繊維を得るために，扔から中に 混在する不溶性タンパク質の除去を主目的とし，酵素的 あるいは化学的処理による“おから食物瀻維”の純化, およびそれに伴うおから粒子形状の経時的変化を走查型 電子顕微鏡（SEM）により観察し，形態の恋化とタン パク質残存量および食物繊維含有量の関連を検討した。 (平成12年 5 月 8 日受付，平成12年 6 月 14 日受理) 